\section{Klokt om makt og hjelp}

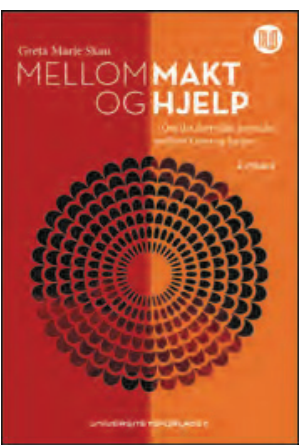

Greta Marie Skau

Mellom makt og hjelp

Om det flertydige forholdet mellom klient

og hjelper. 4. utg. 170 s, ill. Oslo:

Universitetsforlaget, 2013. Pris NOK 329

ISBN 978-82-15-02198-0

Helsefagenes mandat og begrunnelse er etisk. Hensikten er å hjelpe. Derfor behøver fagutøverne kunnskap, handlingsrom og vilje til å utøve kompetent og trygg autoritet. Men med faglig autoritet, eller skal vi våge å kalle det makt, følger dilemmaer og utfordringer. Makt kan misbrukes, selv når intensjonene er gode. Resultatet kan bli krenkelser, avmakt og uhelse for den svake part.

Profesjonsmaktens flertydighet ble knapt tematisert i min studietid. Jeg velger å tro at dagens medisinstudenter oftere inviteres til refleksjon over faglig maktutøvelse, men sannsynligvis er undervisningen personavhengig og usystematisk. Det burde vi kanskje gjøre noe med.

For vitterlig handler medisinens kollektive, og en leges individuelle, mandat til å definere og stille diagnoser og utferdige medisinsk dokumentasjon også om makt. Det er dernest grunn til å dvele ved det som skjer med et menneske i overgangen fra å være en privat og myndig person til en «pasient», «klient» eller «bruker».

Teksten gir god tankehjelp i forhold til en rekke temaer som aktualiserer makt- og hjelpkonstellasjoner i helse- og omsorgstjenesten. Den inneholder dessuten pedagogiske tips hvis man vil stimulere til refleksjon og debatt. Målgruppen er «alle som arbeider med mennesker, og som ønsker å gjøre det på en faglig kompetent og etisk bevisst måte». Forfatteren er sosiolog med bakgrunn fra barne- og ungdomspsykiatrien. Det preger boken på godt og vondt, avhengig av øynene som ser. Teksten er gjennomtenkt og velskrevet. Den veksler mellom teori og eksempler og unngår overforenklinger, svart-hvitt-tenkning og fordømmelser. Tematisk løfter forfatteren gradvis blikket fra individuelle, kliniske møter til kollegialt klima og organisasjonskultur.

Eksemplene hentes i stor grad fra helse- og sosialomsorgen der man oftere snakker om klienter enn om pasienter. Det vil i utgangspunktet appellere mer til andre hjelpeprofesjoner enn til leger. Mellom makt og hjelp kan likevel forventes å finne gjenklang blant leger/studenter som kjenner seg faglig ydmyke i forhold til den autoriteten og makten de innehar, selv i dagens helsetjeneste hvor beretninger om avmektige leger og dehumanisert medisin høres stadig oftere. Kanskje er boken ekstra viktig nettopp nå, for å unngå at egen avmakt smitter over på pasienter og yngre kolleger.

Boken kan gi inspirasjon til undervisning og veiledning av kommende leger og ledere. Teoristoffet kan lett suppleres med andre eksempler enn de forfatteren selv presenterer. Slik kan vi bidra til $ø \mathrm{kt}$ profesjonell bevissthet og en mer humanistisk medisin.

\section{Linn Getz}

Professor, Institutt for samfunnsmedisin

Norges teknisk-naturvitenskapelige universitet

\section{God innføring i helseveiledning}

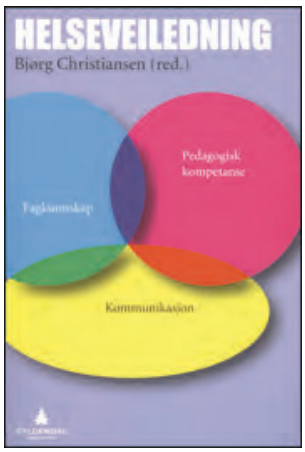

Bjørg Christiansen, red. Helseveiledning

206 s, ill. Oslo: Gyldendal Akademisk, 2013.

Pris NOK 329

ISBN 978-82-05-44350-1

Helseveiledning er blitt en av spesialisthelsetjenestens fire hovedoppgaver ved siden av pasientbehandling, utdanning og forskning. Noen sykehus har derfor opprettet lærings- og mestringssentre. Sykehusinnleggelser er stadig kortere, og utgangspunktet for omfattende helseveiledning er ikke alltid optimalt på sykehus. Samhandlingsreformen formidler klare intensjoner om kommunale lærings- og mestringstilbud for pasienter med blant annet kronisk obstruktiv lungesykdom (kols), diabetes, slag og andre kroniske lidelser. Temaet er sentralt for enkelte strukturelle endringer i vårt helsevesen.

Over noen kapitler gir forfatterne innledningsvis en teoretisk innføring i pedagogiske begreper, teorier og forskning, dessuten faglige perspektiver, oversikt over lovverk og offentlige dokumenter av relevans for emnet. Videre understreker de at det er behov for både standardiserte opplegg og individualiserte tilnærminger som tar hensyn til pasientens tilstand, kontekst og bakgrunn. Bokens definisjon fremholder at helseveiledning er en sammensatt pedagogisk, faglig og kommunikativ prosess der hensikten er å bidra til læring og mestring i helse- og sykdomsrelaterte livssituasjoner.

Bidragsyterne drøfter praktiske utfordringer både $\mathrm{i}$ et individ-, institusjons- og samfunnsperspektiv. De peker på sider ved helseveiledning $\mathrm{i}$ akuttsituasjoner, men også ved forebygging og håndtering av alvorlige sykdommer der hensikten er å bidra til bedring eller motvirke forverring. De nyanserer oppgavene særlig i forhold til eldre, hjerteopererte, de med psykiske reaksjoner, ved flerkulturelle utfordringer og der målet er endring av livsstil og levevaner slik som røyking, overvekt etc.

Boken er lettlest og instruktiv. Redaktøren har skrevet seks av ni kapitler. I tillegg er det bidrag fra Svein Bergvik, Kirsten Halse, Sevald Høye og Tore Sørlie. Målgruppen er særlig sykepleiere, men også andre helseprofesjoner. Særlig innledningsvis kunne kapitlene vært underkastet en noe strengere redigering for å unngå gjentakelser.

Dagens samfunn har mer rasjonell og vitenskapsforankret medisin enn noen gang. Parallelt kan man spore reservasjon i deler av befolkningen mot såkalt «skolemedisin»: Alternativ og komplementær medisin er utbredt. Dette understreker ytterligere behovet for god helseinformasjon og helseveiledning. Denne boken gir en innføring for den som vil nærme seg feltet.

\section{Are Holen}

Professor, Det medisinske fakultet

Norges teknisk-naturvitenskapelige universitet 